\title{
STUDY ON THE PERCEPTION OF ATHLETES IN THE NATIONAL AEROBIC GYMNASTICS TEAM ABOUT THE EXECUTION OF TECHNICAL DIFFICULTY ELEMENTS
}

\author{
Mariana MEZEI ${ }^{1}$ \\ Silvia TEODORESCU ${ }^{2}$ \\ Aura BOTA ${ }^{3}$ \\ ${ }^{1} \mathrm{PhD}$ National University of Physical Education and Sports, Bucharest, ROMANIA, aurabota@ymail.com \\ ${ }^{2}$ Professor PhD National University of Physical Education and Sports, Bucharest, ROMANIA \\ ${ }^{3}$ Professor PhD National University of Physical Education and Sports, Bucharest, ROMANIA
}

\begin{abstract}
Aerobic gymnastics, as a sports branch that highlights the practitioner's complex behavior, creates a wide field of investigation which associates both objective and subjective aspects. This study aims to identify the subjective echo of learning and executing technical elements over the performers, namely their perception about how they are aware of the movement and control it, and also how perception is influenced by variables such as age, gender, sports experience and performance level. To this purpose, a 21-item opinion questionnaire was developed and applied to a number of 25 subjects, members of the national aerobic gymnastics team of Romania.

The study has practical valences, meaning that the information collected from questionnaire was used to design a programme for correcting typical execution mistakes according to the gymnasts' individual particularities. The obtained results imperatively require to approach in preparation some sequences/time for reflection, during which the repeated elements should be brought to discussion by the coach, each athlete providing feedback as regards the psychological pattern used, sensations felt, individual predictive aspects.
\end{abstract}

Key words: perception, aerobic gymnastics, technical elements, training

\section{Introduction}

Performance aerobic gymnastics is a spectacular technical-combinative sport, with complex kinematic elements that exert the athlete's body close to the limit. Competition routines must contain combinations of basic steps and arm movements, all performed to music for creating dynamic, rhythmic and continuous sequences, with changes in the level of execution.

The structure of an aerobic gymnastics routine leads to meeting the difficulty criteria, artistic and execution-related ones (Bota, Mezei, Bidiugan, 2014). The ten difficulty elements in the structure of a routine belong to the four fundamental groups: A -Dynamic strength, B -Static strength, C -Jumps and Leaps, D -Balance and Flexibility, which are reflected in the quality/accuracy of movement and expressiveness in the execution of artistic-motor act.

Technical preparation involves not only acquiring certain elements, but also perceptive or decisionaltype learning (Dragnea, Teodorescu, 2002), useful when reaching higher preparation levels, which have actually represented the premises of our study. These types of learning should be approached homogeneously and progressively

DOI: 10.21279/1454-864X-16-12-069

(c) 2015. This work is licensed under the Creative Commons Attribution-Noncommercial-Share Alike 4.0 License.
(Magill, 1998; Swinnen, 1996; Newell, 1991), obviously with particular notes, depending on the characteristics of each athlete.

In performance aerobic gymnastics, explanatory models of motor control (Schmidt, 1991; Gentile, 1972) provide interesting information on how the gymnast is aware of the movement, the main difficulty consisting in the complexity of actions that simultaneously engage the body segments on different directions, planes and axes, which requires the neuromuscular system to be able to structure and transmit various nervous commands to certain muscle groups recruited selectively, concomitantly or successively.

In this paper, we are concerned with the behavioral area of the learning process, which explains how technical execution can be controlled, as well as the source of possible errors that occur sometimes in both training and competition. These situations involve understanding the influence of feedback (Jordanova, 2005) from the coach or by means of a motion analysis device, and also how muscles and joints are coordinated during movements using a set of intrinsic and extrinsic information. In this context, the gymnast is no longer considered a 


\begin{abstract}
"Mircea cel Batran" Naval Academy Scientific Bulletin, Volume XIX - 2016 - Issue 2
The journal is indexed in: PROQUEST / DOAJ / Crossref / EBSCOhost / INDEX COPERNICUS / DRJI / OAJI /

JOURNAL INDEX / I2OR / SCIENCE LIBRARY INDEX / Google Scholar / Academic Keys/ ROAD Open Access I Academic Resources / Scientific Indexing Services / SCIPIO / JIFACTOR
\end{abstract}

mere mimetic performer, but a processor of information, including the one perceived after making a mistake.

Several authors (B. Cratty, 1973; B. Abernethy, V. Kippers, L. Mackinnon, M. Pandy, 2005; R. Schmidt, T. Lee, 2005) have imagined models that describe and explain how the nervous structure operates to adjust voluntary movements and the dynamics of this process. It is worth noting the aspects related to information processing, the relationship between attention and performance, the sensory and central contributions to achieving motor control.

A critical analysis of specialized literature reveals that the training lesson should represent a continuous source of information/instructions "localized" at different levels: some pieces of information have as source of origin the athlete's body, while others come from the coach or other observers; instructions have different timing as regards execution of the respective movement; practice demonstrates that the coach may indicate either ante-factum a sensory-perceptive objective that helps the athlete to successfully solve the "critical phase" of the practiced element, or postfactum, when the athlete is asked to describe the global sensations felt while performing the element; information may have the goal to increase motivation in the preparation process or make the athletes aware of their success or failure during execution, compared to a certain standard imposed by the Regulations; benchmarks can be designed to be transmitted through one or more sensory channels - demonstration (visual one), explanation (verbal-auditory one), manual guidance and practice while monitoring and objectifying the performed movement (proprioceptive-kinesthetic one).

\section{Methodology}

The purpose of this study is to identify the subjective echo of learning and executing technical elements over the Romanian athletes participating in major competitions organized for aerobic gymnastics.

In this context, we were interested in associating technical preparation methodology with the identification of national team gymnasts' perceptions. The occurrence of typical execution errors has led us to also reflect on the subjective perception of athletes related to the global sensations felt while executing technical elements, as relevant information that can be included in our further approaches to training.

Results obtained from applying the opinion questionnaire and their interpretation

\section{Subjects of the research}

Investigation included 25 gymnasts, members of senior teams between 2012 and 2015. They were applied the questionnaire in the month of September 2014, at the end of some training lessons conducted within the "Lia Manoliu" National Sports Complex.

Subjects agreed to be part of the study, showing their interest in the topic addressed.

\section{Research methods used}

Pedagogical observation (Peretz, 2002; Cerghit, 1997) aimed at finding: the athletes' concentration level in the preparatory phase of the element; how each athlete has created or not his/her own way of handling the respective element, his/her own formula for success; execution compliance with the ideal model, in terms of attitude, technical details, during the three movement phases (preparatory phase, flight and landing); the athletes' level of psycho-affective involvement in the execution; the degree of fatigue and the moment of its onset in the training lesson or during a competition routine.

\section{Questionnaire-based survey method}

The questionnaire (Rotariu, llut, 2006; Miftode, 1995) included 21 items out of which 4 introductory questions, 4 general questions about the specificity and difficulty of sports branch/ events, 10 specific questions about the sensations and perceptions accompanying execution of the two technical elements and 3 questions suggesting possible solutions to improve technical preparation.

The questionnaire is made up of open, unscaled questions, in which subjects had the freedom to express their opinions without the risk of suggestibility, they being offered variants of responses.

\section{Processing methods and graphical-analytical interpretation}

The responses of subjects were coded and entered into the statistical analysis software program SPSS (Labăr, 2008), so that data processing could provide a variety of analyses (Babbie, 2010; Epuran, 2005), allowing to extract as much information as possible from the responses received. We think that the combination of qualitative research with quantitative data analysis (Chelcea, 2007; lluț, 1997) enhances the identification of all information of interest for this study, because statistical analysis provides a description of each variable in the conducted research.

In order to gather relevant data, we have chosen a qualitative-type research, because it enables an indepth understanding and description of how the 
"Mircea cel Batran" Naval Academy Scientific Bulletin, Volume XIX - 2016 - Issue 2

The journal is indexed in: PROQUEST / DOAJ / Crossref / EBSCOhost / INDEX COPERNICUS / DRJI / OAJI /

JOURNAL INDEX I I2OR / SCIENCE LIBRARY INDEX / Google Scholar I Academic Keys/ ROAD Open Access I

Academic Resources / Scientific Indexing Services / SCIPIO / JIFACTOR

athletes perceive technical elements. Predictions resulting from data analysis can thus prove their validity in the training and competitive environment.

The construction of questions has a qualitative character, mainly including nominal and ordinal variables that offer the possibility to obtain personal responses, with direct reference to the practice and experience of each athlete.
The first indicator of interest in this research is the age of participants, which is analyzed as a quantitative variable. In the frequency table, it can be noted that the value with the highest frequency in this distribution is 17 , which suggests that the majority of respondents are aged 17 years. The highest value is 28 years, and the average age is 19 years.

Table1 Statistical data regarding the age of respondents

\begin{tabular}{|l|r|r|}
\hline \multicolumn{2}{|c|}{ Statistics } \\
\hline Age of respondents & & \\
\hline \multirow{N}{*}{} & Valid & 25 \\
\cline { 2 - 3 } & Missing & 0 \\
Median & & 19.00 \\
Minimum & 17 \\
Maximum & & $15 / 17$ \\
\hline
\end{tabular}

The sample included subjects from two generations of athletes, whose particularity was their belonging to two age stages, namely adolescence and young adult periods. This aspect involves several variables related to functional indicators, exercise capacity, level of psycho-emotional function, expressive maturity, level of awareness of the rigors in the preparation process etc.

Table 2 Statistical data regarding the age of respondents

\begin{tabular}{rrrrrr}
\hline \multicolumn{5}{c}{ Age of respondents } & \\
Valid & Frequency & \multicolumn{1}{c}{ Percent } & Valid Percent & Cumulative Percent \\
& 15 & 1 & 4.0 & 4.0 & 4.0 \\
\hline 17 & 7 & 28.0 & 28.0 & 32.0 \\
18 & 3 & 12.0 & 12.0 & 44.0 \\
\hline 19 & 3 & 12.0 & 12.0 & 56.0 \\
21 & 3 & 12.0 & 12.0 & 68.0 \\
22 & 1 & 4.0 & 4.0 & 72.0 \\
23 & 4 & 16.0 & 16.0 & 88.0 \\
\hline 26 & 1 & 4.0 & 4.0 & 92.0 \\
28 & 2 & 8.0 & 8.0 & 100.0 \\
\hline
\end{tabular}

Another indicator of interest analyzed in this research refers to each athlete's seniority in performance sports. This indicator highlights the nature of participants' experience and confirms its importance in formulating opinions about technical execution of difficulty elements. We can note that the average years of practicing performance sports is 10 years, most athletes practicing sports for 8 , respectively 10 years, the highest value being 24 years. 
"Mircea cel Batran" Naval Academy Scientific Bulletin, Volume XIX - 2016 - Issue 2

The journal is indexed in: PROQUEST / DOAJ / Crossref / EBSCOhost / INDEX COPERNICUS / DRJI / OAJI / JOURNAL INDEX I I2OR / SCIENCE LIBRARY INDEX / Google Scholar I Academic Keys/ ROAD Open Access I Academic Resources / Scientific Indexing Services / SCIPIO / JIFACTOR

Table 3 Statistical data regarding seniority in performance sports

\begin{tabular}{|c|c|c|c|c|c|}
\hline \multicolumn{5}{|c|}{ Statistics } & \\
\hline \multicolumn{5}{|c|}{ Seniority in performance sports } & \\
\hline \multirow[t]{2}{*}{$\mathrm{N}$} & \multicolumn{3}{|c|}{ Valid } & 25 & 5 \\
\hline & \multicolumn{3}{|c|}{ Missing } & 0 & 0 \\
\hline \multicolumn{4}{|c|}{ Median } & 10.00 & \\
\hline \multicolumn{4}{|c|}{ Mode } & $8^{\mathrm{a}}$ & $3^{\mathrm{a}}$ \\
\hline \multicolumn{4}{|c|}{ Std. Deviation } & 4.723 & \\
\hline \multicolumn{4}{|c|}{ Minimum } & 6 & 6 \\
\hline \multicolumn{2}{|c|}{ Maximum } & & & 24 & 4 \\
\hline \multicolumn{6}{|c|}{ a. Multiple modes exist. The smallest value is shown } \\
\hline \multicolumn{6}{|c|}{ Seniority in performance sports } \\
\hline & & Frequency & Percent & $\begin{array}{c}\text { Valid } \\
\text { Percent }\end{array}$ & $\begin{array}{c}\text { Cumulative } \\
\text { Percent }\end{array}$ \\
\hline \multirow[t]{15}{*}{ Valid } & 6 & 1 & 4.0 & 4.0 & 4.0 \\
\hline & 7 & 1 & 4.0 & 4.0 & 8.0 \\
\hline & 8 & 5 & 20.0 & 20.0 & 28.0 \\
\hline & 9 & 1 & 4.0 & 4.0 & 32.0 \\
\hline & 10 & 5 & 20.0 & 20.0 & 52.0 \\
\hline & 11 & 2 & 8.0 & 8.0 & 60.0 \\
\hline & 13 & 1 & 4.0 & 4.0 & 64.0 \\
\hline & 14 & 2 & 8.0 & 8.0 & 72.0 \\
\hline & 15 & 1 & 4.0 & 4.0 & 76.0 \\
\hline & 16 & 2 & 8.0 & 8.0 & 84.0 \\
\hline & 17 & 1 & 4.0 & 4.0 & 88.0 \\
\hline & 20 & 1 & 4.0 & 4.0 & 92.0 \\
\hline & 21 & 1 & 4.0 & 4.0 & 96.0 \\
\hline & 24 & 1 & 4.0 & 4.0 & 100.0 \\
\hline & Total & 25 & 100.0 & 100.0 & \\
\hline
\end{tabular}

Another important aspect is related to the results achieved by the athletes in their careers. We think that this element is suggestive because, on the one hand, it provides better knowledge of respondents as subjects, and on the other hand, it may reveal the extent to which the results, the performances achieved in their careers match with the responses they are to give. We notice, in the contingency table, that 13 respondents are medalists at the World Championships, 15 are medalists at the European Championships, 10 at the World Games and 14 gymnasts at the World Cup stages.

(c) 2015. This work is licensed under the Creative Commons Attribution-Noncommercial-Share Alike 4.0 License. 
"Mircea cel Batran" Naval Academy Scientific Bulletin, Volume XIX - 2016 - Issue 2

The journal is indexed in: PROQUEST / DOAJ / Crossref / EBSCOhost / INDEX COPERNICUS / DRJI / OAJI /

JOURNAL INDEX I I2OR / SCIENCE LIBRARY INDEX / Google Scholar I Academic Keys/ ROAD Open Access I

Academic Resources / Scientific Indexing Services / SCIPIO / JIFACTOR

Table 4 Statistical data regarding the sports results of respondents

Gender of respondents* sports carrier achievements- Crosstabulation

\begin{tabular}{|c|c|c|c|c|c|c|c|}
\hline \multicolumn{8}{|l|}{ Count } \\
\hline & & \multicolumn{5}{|c|}{ Sports carrier achievements } & \multirow[b]{2}{*}{ Total } \\
\hline & & $\begin{array}{c}\text { World } \\
\text { Championship } \\
\text { Medalist }\end{array}$ & $\begin{array}{c}\text { European } \\
\text { Championship } \\
\text { Medalist }\end{array}$ & $\begin{array}{l}\text { World } \\
\text { Games } \\
\text { Medalist }\end{array}$ & $\begin{array}{l}\text { World } \\
\text { Cup } \\
\text { Medalist }\end{array}$ & $\begin{array}{c}\text { National } \\
\text { Championship } \\
\text { Medalist }\end{array}$ & \\
\hline \multirow{2}{*}{$\begin{array}{l}\text { Gender of } \\
\text { respondents }\end{array}$} & Male & 5 & 5 & 5 & 7 & 9 & 31 \\
\hline & Female & 8 & 10 & 5 & 7 & 15 & 45 \\
\hline \multicolumn{2}{|l|}{ Total } & 13 & 15 & 10 & 14 & 24 & 76 \\
\hline
\end{tabular}

Identification of crucial elements for the investigated group was followed by some general questions directly related to the technical element studied. Analyzing the following 3 frequency tables, where respondents listed three elements for which they received penalties for execution in recent competitions, we noticed that the Air Turn (Straight
Jump $540^{\circ}$ Turn) and Cossack Jump Turn elements were nominated 12 times. Besides the two elements the most frequently listed as technical elements penalized according to execution criterion, the third place was taken by the Pike Jump element, which received 11 nominations.

\section{Table 5 Statistical data regarding the perceived difficulty of the groups of technical elements}

\begin{tabular}{|c|c|c|c|c|c|c|}
\hline \multicolumn{7}{|c|}{ Gender of respondents * group of elements considered to be difficult- Crosstabulation } \\
\hline \multicolumn{7}{|c|}{ Count } \\
\hline & & \multicolumn{4}{|c|}{ Group of elements considered to be difficult } & \multirow[b]{2}{*}{ Total } \\
\hline & & $\begin{array}{l}\text { Dynamic } \\
\text { strength }\end{array}$ & $\begin{array}{c}\text { Static } \\
\text { strength }\end{array}$ & $\begin{array}{l}\text { Jumps and } \\
\text { Leaps }\end{array}$ & $\begin{array}{c}\text { Balance and } \\
\text { Flexibility }\end{array}$ & \\
\hline \multirow{2}{*}{$\begin{array}{l}\text { Gender of } \\
\text { respondents }\end{array}$} & Male & 2 & 3 & 0 & 4 & 9 \\
\hline & Female & 7 & 8 & 1 & 0 & 16 \\
\hline Total & & 9 & 11 & 1 & 4 & 25 \\
\hline
\end{tabular}

The statistically processed results for this item reveal an interesting and significant aspect for the purpose of this preliminary research. Independently of having chosen for our study the difficulty element C.105, we can find that specific skills in group $\mathrm{C}$ are the most frequently listed by the athletes.

Although this group has not been nominated as a difficult one (to the previous item), however the athletes admit that the most frequent execution mistakes are found in the Jumps group.

Table 6 Statistical data regarding the penalties received for technical elements, according to Execution criterion

\begin{tabular}{|c|c|c|c|c|c|}
\hline \multicolumn{6}{|c|}{ Technical elements that received penalties according to execution criterion } \\
\hline & & Frequency & Percent & Valid percent & Cumulative percent \\
\hline \multirow[t]{6}{*}{ Valid } & free illusion to free vertical split & 2 & 8.0 & 8.0 & 8.0 \\
\hline & 2/1 air turn & 4 & 16.0 & 16.0 & 24.0 \\
\hline & 1/1 turn Cossack jump & 3 & 12.0 & 12.0 & 36.0 \\
\hline & $\begin{array}{l}1 / 2 \text { turn pike jump } 1 / 2 \text { twist to } \\
\text { push up }\end{array}$ & 6 & 24.0 & 24.0 & 60.0 \\
\hline & $\begin{array}{l}1 / 1 \text { turn straddle jump to push up } \\
\text { (Susunova) }\end{array}$ & 1 & 4.0 & 4.0 & 64.0 \\
\hline & straddle planche to lifted Wenson & 1 & 4.0 & 4.0 & 68.0 \\
\hline
\end{tabular}

459

DOI: 10.21279/1454-864X-16-12-069

(C) 2015. This work is licensed under the Creative Commons Attribution-Noncommercial-Share Alike 4.0 License. 
"Mircea cel Batran" Naval Academy Scientific Bulletin, Volume XIX - 2016 - Issue 2

The journal is indexed in: PROQUEST / DOAJ / Crossref / EBSCOhost / INDEX COPERNICUS / DRJI / OAJI / JOURNAL INDEX I I2OR / SCIENCE LIBRARY INDEX / Google Scholar I Academic Keys/ ROAD Open Access I Academic Resources / Scientific Indexing Services / SCIPIO / JIFACTOR

\begin{tabular}{|l|l|r|r|r|r|}
\hline \multirow{2}{*}{} & straddle support & 5 & 20.0 & 20.0 & 4.0 \\
\cline { 2 - 6 } & $\begin{array}{l}\text { high V- support reverse cut 1/2 } \\
\text { twist to split }\end{array}$ & 1 & 4.0 & 88.0 \\
\cline { 2 - 6 } & explosive A- frame to Wenson & 2 & 8.0 & 8.0 & 92.0 \\
\cline { 2 - 6 } & Total & 25 & 100.0 & 100.0 & 100.0 \\
\hline
\end{tabular}

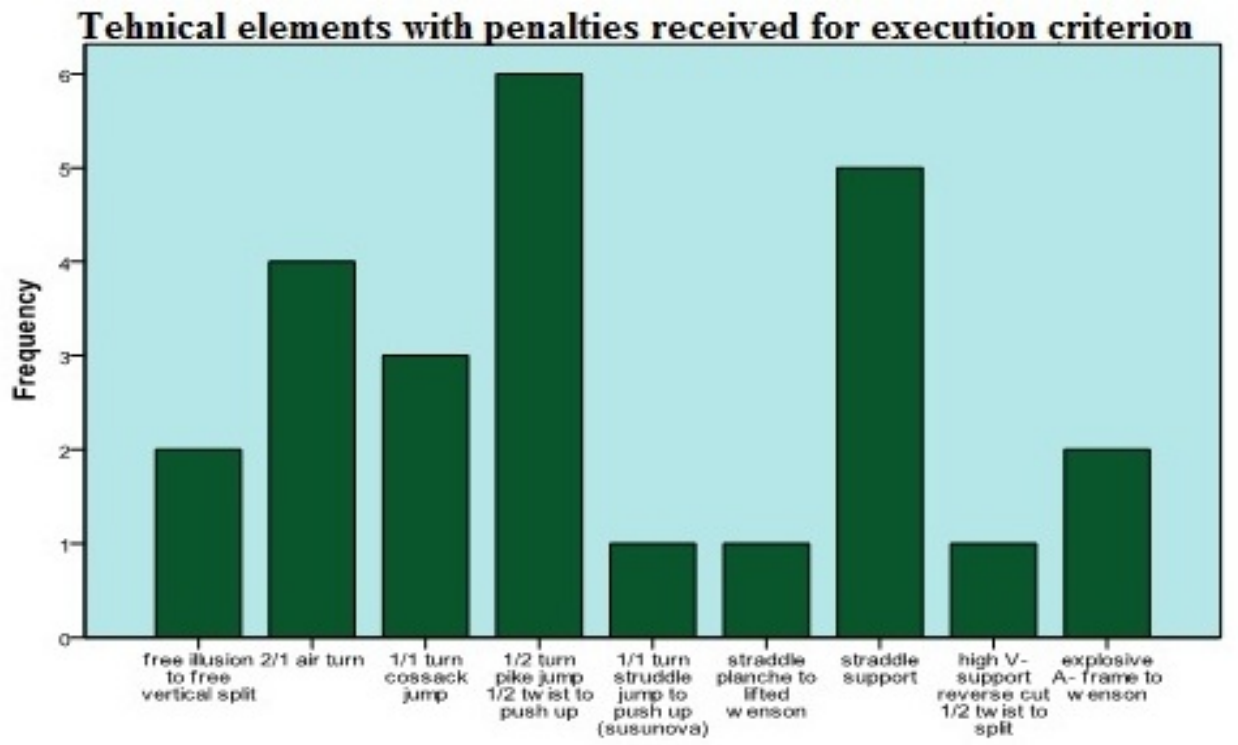

Fig. 1 Distribution of technical elements that received penalties

The Pike Jump element, listed $1^{\text {st }}$, is also included into the Jumps group, having the same biomechanical structure of swing phase as element C.105. Flight phase is also performed with rotation around the vertical axis, which involves the same mechanism of ante-factum movement adjusting and the same possibilities of generating an execution error, especially in the swing phase.

The following items mainly analyze element C.105 Air Turn, the first variable of interest being related to its phase that requires the highest mental concentration, namely the swing, as considered by the respondent.

Table 7 Statistical data regarding the phases of elements requiring intense concentration Phase of element $C .105$ that requires the most intense concentration Frequency Percent Valid Percent Cumulative percent

\begin{tabular}{llrrrr} 
Valid & Swing & 12 & 48.0 & 48.0 & 48.0 \\
& Flight phase & 6 & 24.0 & 24.0 & 72.0 \\
& Landing & 7 & 28.0 & 28.0 & 100.0 \\
& Total & 25 & 100.0 & 100.0 & \\
\hline
\end{tabular}

Athletes are aware that, for this jump, the body position does not present changes in its form during the flight phase, but only involves an increased rotation speed, which, theoretically, is correctly perceived by the respondents.

To have an even more accurate picture of how the element frequency has been achieved, we

Table 8 Statistical data regarding the phases of elements that require intense concentration, by gender associated this variable with the gender variable, therefore we can notice that 4 of the 9 male respondents consider the swing as the element phase that requires the highest concentration, and 8 of the 16 female respondents share the same opinion. 
"Mircea cel Batran" Naval Academy Scientific Bulletin, Volume XIX - 2016 - Issue 2

The journal is indexed in: PROQUEST / DOAJ / Crossref / EBSCOhost / INDEX COPERNICUS / DRJI / OAJI / JOURNAL INDEX / I2OR / SCIENCE LIBRARY INDEX / Google Scholar / Academic Keys/ ROAD Open Access I Academic Resources / Scientific Indexing Services / SCIPIO / JIFACTOR

\begin{tabular}{|c|c|c|c|c|}
\hline Gender of respondents & $\begin{array}{r}\text { hase of element C.105 } \\
\text { Crosstabu }\end{array}$ & $\begin{array}{l}\text { at requires the } \\
\text { tion }\end{array}$ & ense concentrati & \\
\hline Count & & & & \\
\hline & Phase of element C.105 & at requires the $\mathrm{m}$ & Ise concentration & \\
\hline & Swing & Flight phase & Landing & Total \\
\hline Gender of respondents Male & 4 & 4 & 1 & 9 \\
\hline Female & 8 & 2 & 6 & 16 \\
\hline Total & 12 & 6 & & 25 \\
\hline
\end{tabular}

We also notice that landing represents the element phase requiring intense concentration only for female respondents, 6 of the 8 gymnasts ticking this response.

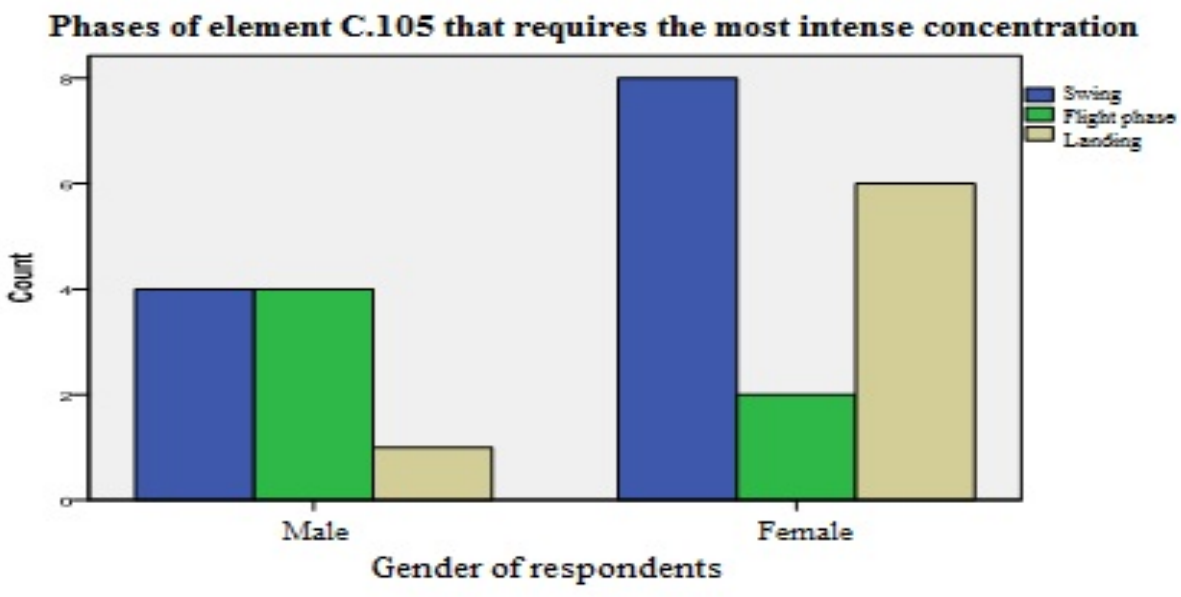

Fig. 2 Distribution of intense concentration phase, by gender

The next variable refers to the frequency of execution mistakes in the phases of element C.105

- Air Turn. It can be noted that the phase where most mistakes are made is that of swing, 13 of the 25 gymnasts ticking this response.

\section{Table 9 Statistical data regarding the phase of technical elements where execution mistakes occur frequently}

Frequency of execution mistakes when performing element C.105

Frequency Percent Valid Percent Cumulative percent

\begin{tabular}{llrrrr} 
Valid & Swing & 13 & 52.0 & 52.0 & 52.0 \\
& Flight phase & 2 & 8.0 & 8.0 & 60.0 \\
& Landing & 10 & 40.0 & 40.0 & 100.0 \\
& Total & 25 & 100.0 & 100.0 & \\
\hline
\end{tabular}

(c) 2015. This work is licensed under the Creative Commons Attribution-Noncommercial-Share Alike 4.0 License. 
"Mircea cel Batran" Naval Academy Scientific Bulletin, Volume XIX - 2016 - Issue 2

The journal is indexed in: PROQUEST / DOAJ / Crossref / EBSCOhost / INDEX COPERNICUS / DRJI / OAJI / JOURNAL INDEX I I2OR / SCIENCE LIBRARY INDEX / Google Scholar I Academic Keys/ ROAD Open Access I Academic Resources / Scientific Indexing Services / SCIPIO / JIFACTOR

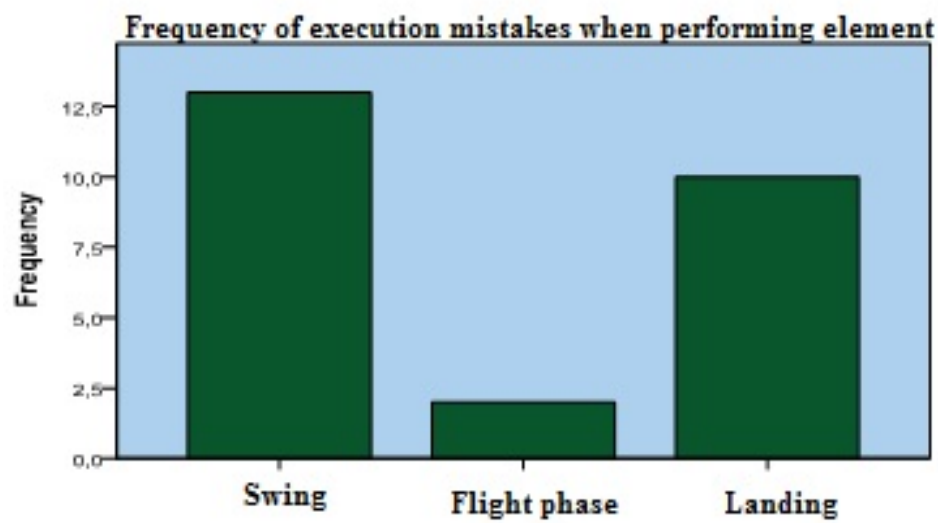

Fig.3 Distribution of occurred execution mistakes in the three phases of technical element

Athletes believe, to an almost equal extent, that execution errors frequently occur in the swing phase and landing phase, which is also confirmed by the judging sheets. Actually, the judge can penalize both the first and last phase, the two movement sequences being in influential relationships.

In the table below, we correlated two variables, namely the phase requiring the most intense concentration and the phase during which most execution mistakes occur, in order to see if there is a positive association between them, more exactly if they influence each other.

According to the correlation coefficient value of 0.614 shown in the table below, we note that there is a positive association between the two variables, which suggests that those who consider a certain phase of the element as requiring the most intense concentration also consider it as the phase where they make the greatest number of mistakes. The lowest values

Table 10 Statistical data regarding the correlation between mental concentration required and frequency

\begin{tabular}{|c|c|c|c|}
\hline \multicolumn{4}{|c|}{ Correlation } \\
\hline \multicolumn{2}{|c|}{ Variables } & $\begin{array}{l}\text { Phase of elementC.105 } \\
\text { requiring the most intense } \\
\text { concentration }\end{array}$ & $\begin{array}{c}\text { Frequency of execution } \\
\text { mistakes when performing } \\
\text { element C.105 }\end{array}$ \\
\hline \multirow{3}{*}{$\begin{array}{l}\text { Phase of elementC.105 } \\
\text { requiring the most intense } \\
\text { concentration }\end{array}$} & Pearson Correlation & $\begin{array}{r}1 \\
\end{array}$ & $.614^{* *}$ \\
\hline & Sig. (2-tailed) & & .001 \\
\hline & $\mathbf{N}$ & 25 & 25 \\
\hline \multirow{3}{*}{$\begin{array}{l}\text { Frequency of execution } \\
\text { mistakes when performing } \\
\text { element C.105 }\end{array}$} & Pearson Correlation & $.614^{* *}$ & 1 \\
\hline & Sig. (2-tailed) & .001 & \\
\hline & $\mathbf{N}$ & 25 & 25 \\
\hline
\end{tabular}

of the variable phase of element C.105 that requires the most intense concentration correspond to the lowest values of the variable frequency of execution mistakes when performing element C.105. Given that the correlation coefficient can be calculated between two numerical variables, we coded the "swing", "flight phase" and "landing" values of the two ordinal variables with conventionally-chosen numerical values, namely 1,2 and 3 , in order to measure the relationship between the two variables. The result of SPSS statistical analysis indicates the existence of a positive correlation between the two variables, which helps us make certain predictions and facilitates our exploration and a more accurate knowledge of the defining components in the execution of element C.105 - Air Turn.

Statistical correlation is highly significant for a threshold of $99 \%$.

\section{of execution mistakes occurred
of}


"Mircea cel Batran" Naval Academy Scientific Bulletin, Volume XIX - 2016 - Issue 2

The journal is indexed in: PROQUEST / DOAJ / Crossref / EBSCOhost / INDEX COPERNICUS / DRJI / OAJI /

JOURNAL INDEX I I2OR / SCIENCE LIBRARY INDEX / Google Scholar I Academic Keys/ ROAD Open Access I

Academic Resources / Scientific Indexing Services / SCIPIO / JIFACTOR

The variable related to the factors leading to execution mistakes for element C.105 - Air Turn reveals, according to the frequency table below, that the lack of concentration is the main factor leading to execution mistakes, 11 of the 25 gymnasts ticking this response.

Table 11 Statistical data regarding the factors leading to execution mistakes

\begin{tabular}{|l|l|r|r|r|r|}
\hline \multicolumn{6}{|c|}{ Factors leading to execution mistakes for the technical element C.105 } \\
\hline Valid & Frequency & Percent & Valid Percent & \multicolumn{1}{c|}{ Cumulative percent } \\
\hline & Lack of concentration & 11 & 44.0 & 44.0 & 44.0 \\
\cline { 2 - 6 } & $\begin{array}{l}\text { Inappropriate movement } \\
\text { pattern }\end{array}$ & 8 & 32.0 & 32.0 & 76.0 \\
$\begin{array}{l}\text { Element inclusion into the } \\
\text { choreographic composition } \\
\text { Total }\end{array}$ & 6 & 24.0 & 24.0 & 100.0 \\
\hline
\end{tabular}

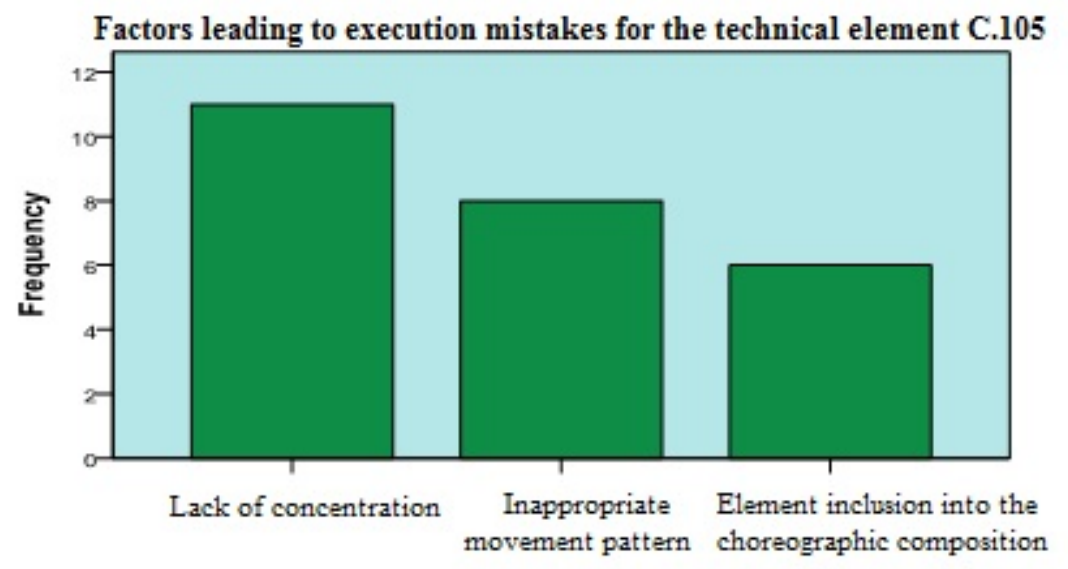

Fig. 4 Distribution of factors leading to occurrence of execution mistakes

The analysis of factors leading to execution errors shows a hierarchy indicating that lack of concentration is on the $1^{\text {st }}$ place, inappropriate movement pattern is on the $2^{\text {nd }}$ place, and element positioning within the routine, on the $3^{\text {rd }}$ place. Responses to this item correlate with those that aim at the phase requiring the most intense concentration. Improper learning of execution technique is another reason listed by the respondents, which involves the need to apply programmes designed for correcting and properly learning the respective motor skill.

To item 13, relating to the aspects on which the gymnast focuses when performing the element, we have noticed that the majority of subjects generically nominate only the swing and landing phases, without taking into account the flight and implicitly the body position in the air, which should be felt specifically by each gymnast. We could say that many times the athletes are not aware and do not internalize sufficiently the corrections of coaches, purposely directed to these aspects.

The next question refers to the number of repetitions that each respondent performs during a training lesson for the two elements, being followed by an item referring to the optimal number of repetitions that should be performed for each element, in the opinion of respondents. It can be noted from the table below that there is a minimum of 5 repetitions for the 4 numerical variables mentioned in the questionnaire and a maximum of 20 repetitions for the number of repetitions performed during the training lessons, for element C.105.

As regards the optimal number of repetitions that should be performed for both elements, the subjects indicated a maximal number of 40 repetitions, twice more than the maximal number of repetitions that they normally perform during training. 
"Mircea cel Batran" Naval Academy Scientific Bulletin, Volume XIX - 2016 - Issue 2

The journal is indexed in: PROQUEST / DOAJ / Crossref / EBSCOhost / INDEX COPERNICUS / DRJI / OAJI /

JOURNAL INDEX I I2OR / SCIENCE LIBRARY INDEX / Google Scholar / Academic Keys/ ROAD Open Access I

Academic Resources / Scientific Indexing Services / SCIPIO / JIFACTOR

Table 12 Statistical data regarding the number of repetitions performed and the optimal number of repetitions for the technical element

\begin{tabular}{lccccc}
\hline & \multicolumn{3}{c}{ Descriptive statistics } & Mean & Std. Deviation \\
& N & Minimum & Maximum & 11.60 & 3.640 \\
$\begin{array}{l}\text { Number of repetitions performed } \\
\text { for element C.105 }\end{array}$ & 25 & 5 & 20 & 15.64 & 7.675 \\
$\begin{array}{l}\text { Optimal number of repetitions } \\
\text { that should be performed for }\end{array}$ & 25 & 5 & 40 & & \\
$\begin{array}{l}\text { element C.105 } \\
\text { Valid N (listwise) }\end{array}$ & 25 & & & & \\
\hline
\end{tabular}

The contingency tables below show the distribution of the number of repetitions performed, as well as those considered to be optimal for each element, in the opinion of respondents, by gender. It is noticed that male respondents perform a greater number of repetitions for both elements, and as regards the number of repetitions considered to be optimal, the male respondents also opt for a greater number of executions.

Table 13 Statistical data regarding the number of repetitions performed, by gender

Gender of respondents * number of repetitions performed for the technical element C.105 - Crosstabulation

\begin{tabular}{|ll|r|r|r|r|r|r|r|r|r|r|}
\hline & & \multicolumn{6}{|c|}{ Number of repetitions performed for the technical element C.105 } \\
\cline { 3 - 10 } & & 5 & 7 & 8 & 10 & 15 & 16 & 17 & 20 & Total \\
\hline $\begin{array}{l}\text { Gender of } \\
\text { respondents }\end{array}$ & Male & 1 & 0 & 0 & 5 & 2 & 0 & 0 & 1 & 9 \\
& Female & 0 & 2 & 1 & 7 & 4 & 1 & 1 & 0 & 16 \\
\hline
\end{tabular}

The different number of repetitions performed and their optimal number for girls and boys can be argued by the increased level of explosive strength of the latter, which favors economical energy consumption and the possibility to perform a greater volume of repetitions. In their turn, the female gymnasts accuse overstrain symptoms in the lower limb joints, also caused by the characteristics of the hard surface on which they work.

We considered it interesting to find if the age of respondents interferes with the number of repetitions they perform. From the correlation table below, it is noted that there is a positive association between the age of respondents and the number of repetitions, younger respondents performing a smaller number of repetitions, while older respondents, an increased number of repetitions. It is also noted that this correlation is stronger for element C.105, which suggests that respondents perform a different number of repetitions for the two elements, according to age.

Table 14 Statistical data regarding the correlation between the number of repetitions performed, by age/ element C.105

\begin{tabular}{|ll|r|r|}
\hline & \multicolumn{1}{|c|}{$\begin{array}{c}\text { Age of } \\
\text { respondents }\end{array}$} & $\begin{array}{c}\text { Number of repetitions performed } \\
\text { for the technical element C.105 }\end{array}$ \\
\hline Age of respondents & Pearson Correlation & 1 & .107 \\
& Sig. (1-tailed) & & .305 \\
& $\mathrm{~N}$ & 25 & 25 \\
\hline Number of repetitions performed & Pearson Correlation & .107 & 1 \\
\cline { 2 - 4 } & Sig. (1-tailed) & .305 & 25 \\
\cline { 2 - 4 } & $\mathrm{N}$ & 25 & \\
\end{tabular}

At the same time, it is noted that the Pearson coefficient value is 0.107 for the correlation between

the age variable and the variable relating to the number of repetitions performed for element C.105. 
"Mircea cel Batran" Naval Academy Scientific Bulletin, Volume XIX - 2016 - Issue 2

The journal is indexed in: PROQUEST / DOAJ / Crossref / EBSCOhost / INDEX COPERNICUS / DRJI / OAJI /

JOURNAL INDEX I I2OR / SCIENCE LIBRARY INDEX / Google Scholar I Academic Keys/ ROAD Open Access I

Academic Resources / Scientific Indexing Services / SCIPIO / JIFACTOR

Secondly, we can see that the two dependent variables, number of repetitions performed for element C.105, show a positive relationship with the age variable, but of low intensity, determined by the correlation values close to 0 . Statistical significance of the coefficient (Sig.) is 0.01 , which suggests that the error probability is negligible, and this analysis is significant for the athletes studied.

The upward direction of point cloud in the positive correlation graph suggests that as one of the variables increases, the other has the same upward trend.

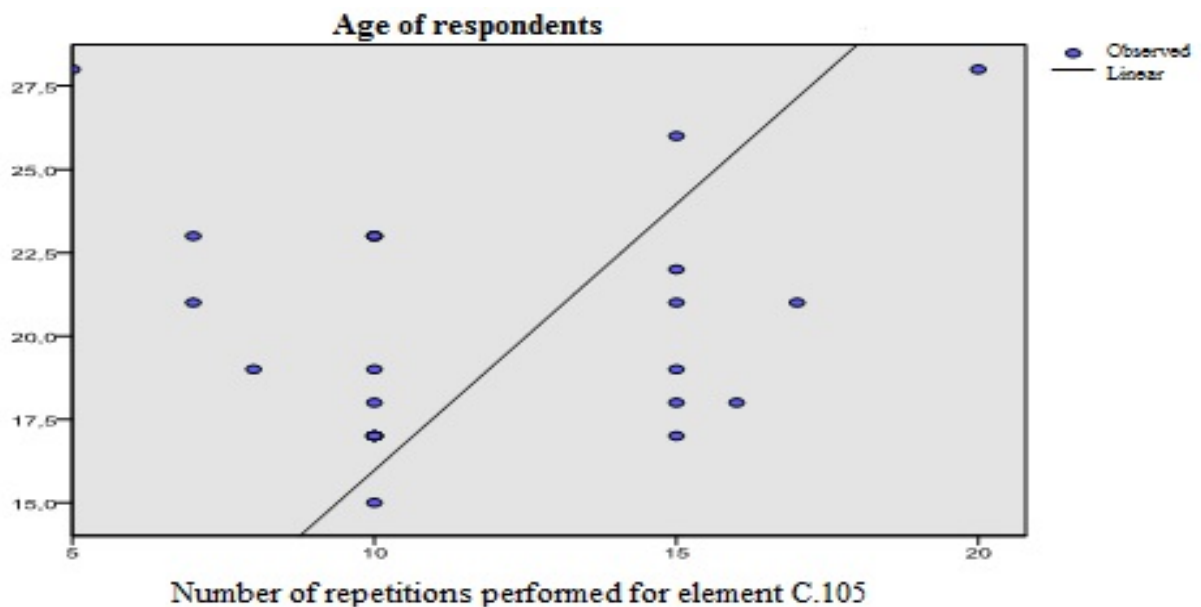

Fig. 5 Representation of the correlation between the number of repetitions performed and the age of gymnasts, for element C.105 - 2/1 Air turn

The explanation for this positive correlation lies undoubtedly in the higher level of maturity of the experienced gymnasts, aware that only the over learning of technical elements reduces the occurrence of execution mistakes and creates the premises for specialized senses, through which gymnasts can detect and finely tune the movement parameters, under stress and fatigue conditions.
A final question refers to how the respondents think that they can eliminate execution mistakes. According to the frequency table below, it can be firmly stated that the use of technique correction exercises in the training lessons is the variant for which most of the respondents have opted.

\section{Table15 Statistical data regarding some useful methods to eliminate execution mistakes}

\begin{tabular}{|c|c|c|c|c|c|}
\hline \multicolumn{6}{|c|}{ Methods to eliminate execution mistakes } \\
\hline & & Frequency & Percent & Valid percent & Cumulative percent \\
\hline \multirow[t]{5}{*}{ Valid } & $\begin{array}{l}\text { using in the training lesson } \\
\text { some motion analysis } \\
\text { devices that allow } \\
\text { visualization of one's own } \\
\text { executions }\end{array}$ & 4 & 16.0 & 16.0 & 16.0 \\
\hline & using mental training & 1 & 4.0 & 4.0 & 20.0 \\
\hline & $\begin{array}{l}\text { using equipment for the } \\
\text { biomechanical study of } \\
\text { difficulty elements }\end{array}$ & 3 & 12.0 & 12.0 & 32.0 \\
\hline & $\begin{array}{l}\text { using technique correction } \\
\text { exercises during the training } \\
\text { lessons }\end{array}$ & 17 & 68.0 & 68.0 & 100.0 \\
\hline & Total & 25 & 100.0 & 100.0 & \\
\hline
\end{tabular}


"Mircea cel Batran" Naval Academy Scientific Bulletin, Volume XIX - 2016 - Issue 2

The journal is indexed in: PROQUEST / DOAJ / Crossref / EBSCOhost / INDEX COPERNICUS / DRJI / OAJI /

JOURNAL INDEX / I2OR / SCIENCE LIBRARY INDEX / Google Scholar / Academic Keys/ ROAD Open Access I

Academic Resources / Scientific Indexing Services / SCIPIO / JIFACTOR

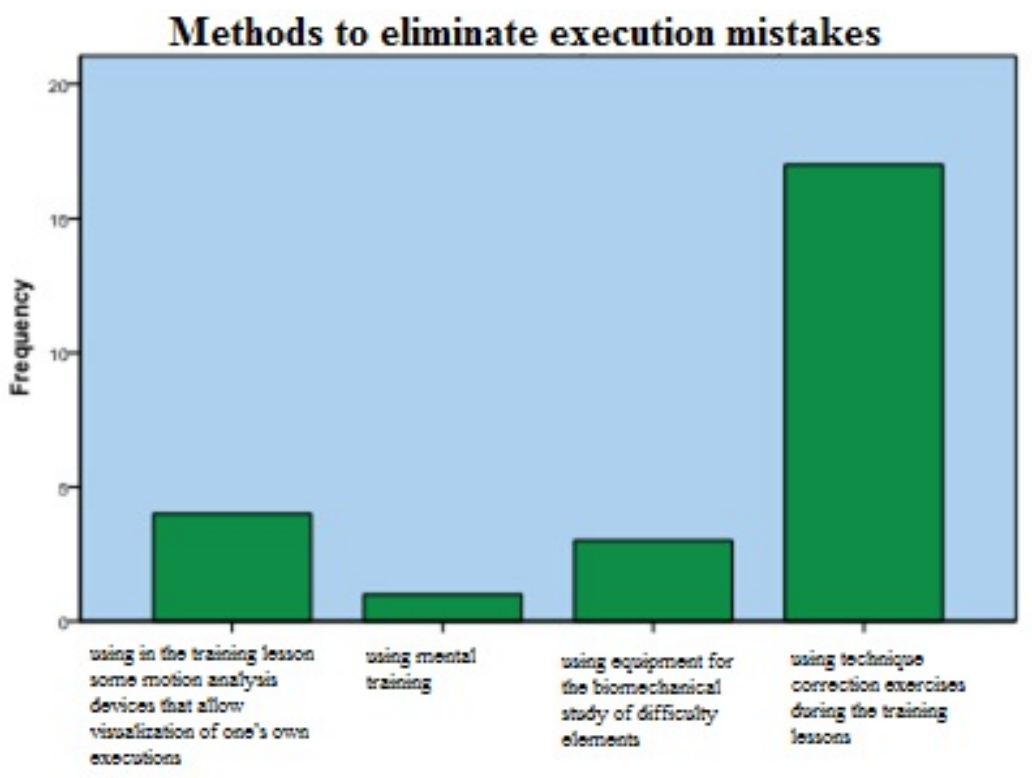

Fig. 6 Distribution of methods to eliminate execution mistakes

As regards the hierarchy of methods to correct execution mistakes, one can clearly notice that the athletes give credit to traditional approaches used in the process of their formation as athletes. It becomes obvious that modern training methodology, which combines biomechanical and psychological approaches, is still insufficiently valued by the subjects, despite the clear advantages they provide.

The obtained results imperatively require to approach in preparation some sequences/time for reflection, during which the repeated element should be brought to discussion by the coach, each athlete providing feedback as regards the psychological pattern used, sensations felt, individual predictive aspects. On the other hand, athletes should become familiar with the benefits of training based on prosthetic information, as a complementary means that adjusts/corrects aspects which usually escape their conscious sphere.

\section{CONCLUSIONS}

After the first stages of learning the technique, in aerobic gymnastics it is necessary to create mechanisms able to ensure, through a trans-disciplinary strategy, the perfect motor control of movement.

The 21 items of the opinion questionnaire included general aspects regarding the subjects' sports profile, elements aimed at the specificity and difficulty of sports branch/events, aspects aimed at the sensations and perceptions accompanying execution of the two technical elements and questions suggesting possible solutions to improve technical preparation.

An interesting aspect revealed by statistical calculation refers to the positive correlations between the technical phase/phases that require(s) the most intense concentration and that/those where most execution mistakes are made.

The intrinsic analysis of data regarding the factors that lead to execution mistakes for element C.105 highlights a majority opinion related to the importance of mental concentration and the inappropriate mechanism of performing the two skills.

Information about the number of executions performed and the optimal number of repetitions reflects that the athletes have different approaches, according to their age and gender, which means a more mature understanding of the importance of the practice volume, in the case of experienced gymnasts.

As regards the hierarchy of methods to correct execution mistakes, one can clearly notice that the athletes give credit to traditional approaches used in the process of their formation as athletes. It becomes obvious that 
"Mircea cel Batran" Naval Academy Scientific Bulletin, Volume XIX - 2016 - Issue 2

The journal is indexed in: PROQUEST / DOAJ / Crossref / EBSCOhost / INDEX COPERNICUS / DRJI / OAJI /

JOURNAL INDEX / I2OR / SCIENCE LIBRARY INDEX / Google Scholar / Academic Keys/ ROAD Open Access I

Academic Resources / Scientific Indexing Services / SCIPIO / JIFACTOR

modern training methodology, which combines biomechanical and psychological approaches, is still insufficiently valued by the subjects, despite the clear advantages they provide.

\section{BIBLIOGRAPHY}

[1] Abernethy, B., Hanrahan, S. J., Kippers, V., Mackinnon L. T., Pandy, M.G., (2005), The Biopsychical Foundations of Human Movement, Human Kinetics.

[2] Abernethy, B., Wann, J., Parks, S., (1998), Training perceptual-motor skills for sport, În Training in sport: applying sport science, Wiley, Chichester.

[3] Babbie, E., (trad.rom. 2010), Practica cercetării sociale, Ed. Polirom, lași.

[4]Bota, A., Mezei, M., Bidiugan, R., (2014), Enhancing technical accuracy in high-level aerobic gymnastics by means of mvn motion capture systems". În International Scientific Conference on eLearning and Software for Education. Else 2014. "Carol I" National Defence University, Bucharest.

[5] Cerghit, I., (1997), Metode de învăţământ, Editura Didactică şi Pedagogică, București.

[6] Chelcea, S., (2000), (2007), Metodologia cercetării sociologice. Metode cantitative şi calitative (ediţia a III-a), Ed. Economică, Bucureşti.

[7] Cratty, B., (1973), Teaching motor skills, Prentice-Hall.

[8] Dragnea, A., Teodorescu S., (2002), Teoria Sportului, Ed. FEST, București.

[9] Durkheim, É., (trad. rom. 1974), Regulile metodei sociologice, Ed. Ştiinţifică şi Enciclopedică, Bucureşti.

[10] Epuran, M., (2013), Motricitate și psihism în activitățile corporale, Ed. FEST, București.

[11] Epuran, M., (2005), Metodologia cercetării activităților corporale, Ed. a 2-a, FEST, București.

[12] Gentile, A., (1972), A working model of skill acquisition with application to teaching. În Quest, 17.

[13] Iluţ, P., (1997), Abordarea calitativă a socioumanului. Concepte şi metode. Ed. Polirom, laşi.

[14] Jordanova, N., (2005), Biofeedback Training for Peack Performance in Sport-Case Study. În Macedonian Journal of Medical Sciennces. Jun 15;3(2):113-118.

[15] Magill, R., A., (1998), Motor learning:concepts and applications,5th. Ed. , Mc.Graw-Hill, Boston.

[16] Magill, R., A., (2001), Augmented feed-back in motor skill acquisition, În Handbook of sport psychology.

[17] Miftode, V., (1995), Metodologia sociologică, Editura Porto Franco, Galaţi.

[18] Newell, K., (1991), Motor skill acquisition, În Annual Review of Psychology, 42.

[19] Peretz, H., (trad. rom 2002), Metodele în sociologie. Observaţia, Ed. Institutul European. Iaşi.

[20] Rotariu, T., lluţ, P. (1997, 2006), Ancheta sociologică şi sondajul de opinie. Teorie şi practică (ediţia a II-a),

Ed. Polirom, laşi.

[21] Schmidt R., Lee T. (2005), Motor Control and Learning-a Behavioral Emphasis, Human Kinetics.

[22] Schmidt, R., A., (1991), Motor learning \& performance-from principles to practice, Human Kinetics Books, Human Kinetics, Illinois.

[23] Swinnen, S., (1996), Information feed-back for motor skill learning: A review, În Advances in motor learning and control. 